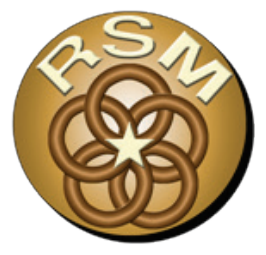

\title{
Identification of Alternatives to Reduce Shoaling in the Lower Matagorda Ship Channel, Texas
}

\author{
by Eric Wood, Tricia Campbell, Matt Duke, Leslie Olson,
} Lauren Dunkin, and Lihwa Lin

PURPOSE: The purpose of this U.S. Army Corps of Engineers (USACE) Regional Sediment Management Technical Note (RSM-TN) is to document the development of a regional sediment budget and to investigate design alternatives to reduce shoaling in the lower Matagorda Ship Channel (MSC). This RSM-TN focuses on the MSC between channel Station 10+000 and Station $60+000$ as well as the Gulf Intracoastal Waterway (GIWW) immediately adjacent to the MSC where the two waterways intersect (Figure 1). Placement Areas (PAs) 6 through 10 are within the focus area. During the genesis of this study, researchers predicted that these PAs were contributing to the shoaling issue in the focus area. The goal of this study is to identify alternatives that will reduce shoaling in the focus area and increase intervals between required maintenance dredging.

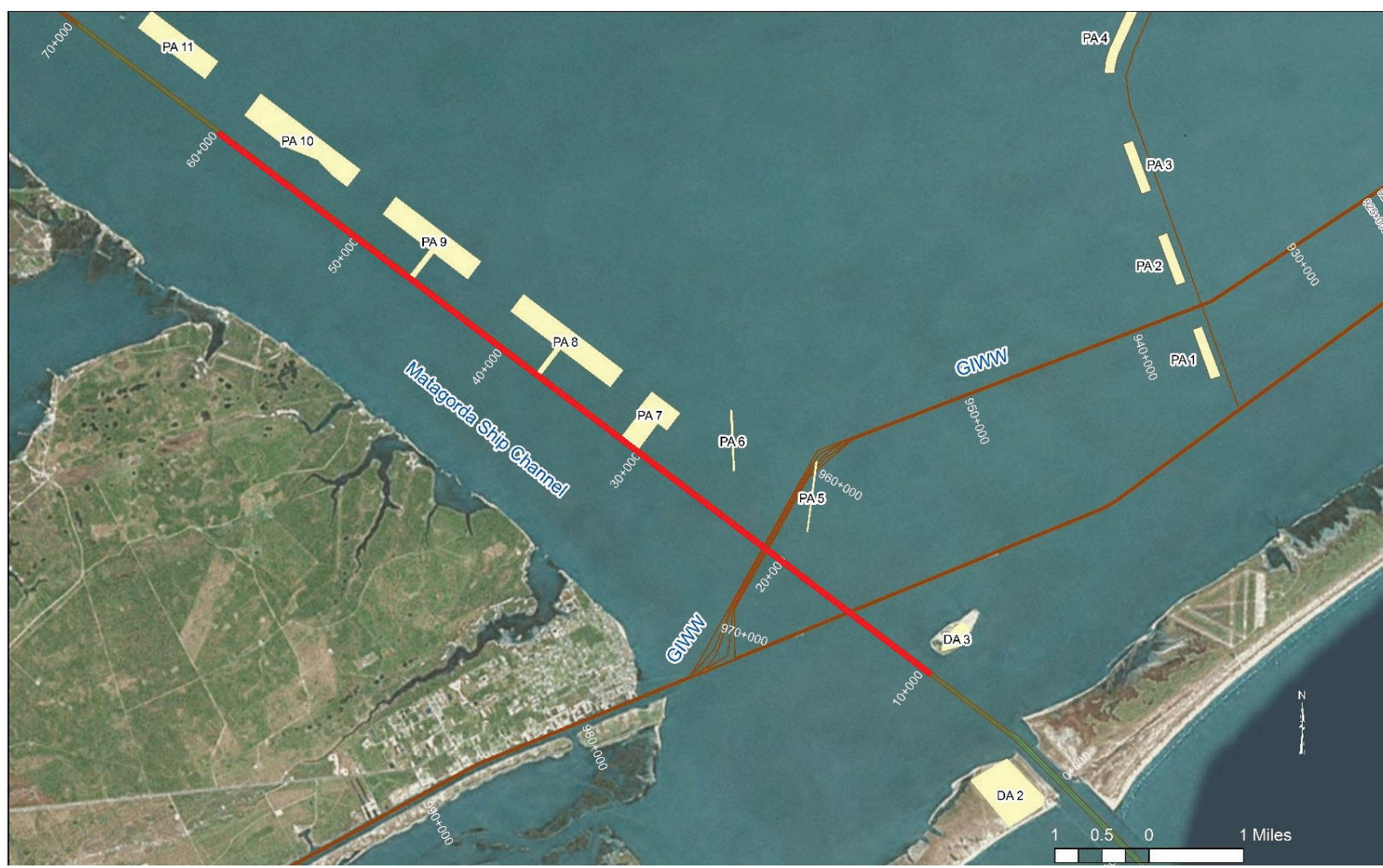

Figure 1. Lower Matagorda Ship Channel, TX, study area (channel Station 10+000 to Station 60+000). 
INTRODUCTION: Regional Sediment Management (RSM) refers to the effective use of littoral, estuarine, and riverine sediment resources in an environmentally sensitive and economically efficient manner (Lillycrop et al. 2011). This USACE RSM project focuses on Matagorda Bay and the lower MSC where shoaling has led to draft restrictions and ship transit delays in recent years. MSC is a deep-draft navigation channel that provides access to the cities and ports of Port Lavaca and Point Comfort. Shoaling in the MSC study vicinity has become a frequent issue that impacts navigation, causes lightering of ships, ship transit delays, and redirection of ships to other ports. Excessive shoaling has required reduced vessel operating drafts for extended periods. The problem seems to have worsened in recent years causing MSC pilots, via the Calhoun Port Authority (the Non-Federal Sponsor), to report this issue to the USACE Galveston District (SWG). MSC pilots relayed through the Port Authority that they believed the major issue is dredged material placed in open bay PAs 6 through 10 is shoaling back into the channel.

Records indicate the MSC has not had adequate project depth since 1997. In addition, changes in the bay may be affecting the bay hydraulics. Approximately a month after completion of the most recent dredging effort, the pilots became concerned with decreased vessel control when entering the area. Pilots identified specific channel reaches of concern, and these channel reaches became the focus area of this study. The pilots and the Calhoun Port Authority stated that they believed decreased vessel control due to shoaling was becoming worse and more frequent.

The region of primary concern is from channel Station $10+000$ to Station $40+000$ (Markers 33/34 to Markers 31/32). For this effort, USACE performed additional analysis of the MSC, which covered Stations $0+000$ to $60+000$, to develop a better understanding of the shoaling issues and the processes causing those shoaling issues as described in USACE (2002). PAs 6 through 10 serve as PAs for material dredged from the adjacent MSC within the study focus area. These PAs also serve, to a lesser extent, as PAs of dredged material from the GIWW in the immediate vicinity of the intersection of the MSC and GIWW.

\section{DATA COLLECTION}

Datum information. The National Oceanic and Atmospheric Administration (NOAA) Center for Operational Oceanographic Products and Services (CO-OPS) manages a permanent observing system, the National Water Level Observation Network (NWLON). Vertical datum information for the study area obtained from NWLON Station Port O'Connor (Station ID 8773701) is listed in Table 1. The North American Vertical Datum of 1988 (NAVD88) datum information was determined using the latest USACE survey information for Port O'Connor.

\begin{tabular}{|l|l||l||}
\hline \multicolumn{3}{|l|}{ Table 1. Datum elevation information. } \\
\hline Datum & Value & Description \\
\hline \hline MHHW & 12.25 & Mean Higher-High Water \\
\hline MHW & 12.23 & Mean High Water \\
\hline MTL & 11.86 & Mean Tide Level \\
\hline MSL & 11.88 & Mean Sea Level \\
\hline MLW & 11.48 & Mean Low Water \\
\hline MLLW & 11.45 & Mean Lower-Low Water \\
\hline NAVD88 & 11.09 & North American Vertical Datum of 1988 \\
\hline MLT & 10.26 & Mean Low Tide \\
\hline
\end{tabular}


Historical channel data. In 1910, Congress authorized an 8 mile long channel at a depth of 7 feet (ft.) Mean Low Tide (MLT) and $80 \mathrm{ft}$. wide from lower Matagorda Bay to Port Lavaca (Relationship between MLT and Mean Lower Low Water (MLLW) is shown in Table 1.) The upper end of the channel was extended a distance of about 1 mile to the shoreline at the entrance of Lynn Bayou in 1935. In 1937, the channel was enlarged from Lynn Bayou at Port Lavaca to lower Matagorda Bay near Port O'Connor. This channel had a depth of $9 \mathrm{ft}$. MLT and a width of $100 \mathrm{ft}$., and was 11 miles long. In 1945, a $100 \mathrm{ft}$. wide and $6 \mathrm{ft}$. deep MLT channel extension was created through the Lavaca River and Navidad River to Red Bluff, which is located at mile 3 on the Navidad River. The 1958 deepening and widening encompassed a total distance of 20 miles. Also in 1958, an inner channel $36 \mathrm{ft}$. deep MLT, $200 \mathrm{ft}$. wide, and 22 miles long was constructed across Matagorda and Lavaca Bays. A $36 \mathrm{ft}$. deep turning basin at Point Comfort and dual jetties were also constructed at the channel entrance in 1958. These dimensions remain the present-day measurements of the MSC channel (USACE 2009).

In 2007, the GIWW and MSC intersection was modified and shifted approximately 2 miles north to its present location (URS 2007 [rev. 2014]). The GIWW channel shift in 2007 led to material that would have previously been placed at Sundown Island Disposal Area 3 (DA3) (Figure 1) now being placed in PAs 6 through 10. The shift in the location of the GIWW to its current location takes advantage of the natural bay bottom, results in a more stable channel, decreases shoaling, and, therefore, requires less frequent maintenance dredging.

Historical dredging data. To estimate annual shoaling rates in the MSC and gather data to create a sediment budget, historical dredging quantities from 1957 to 2012 were obtained from the SWG dredging histories database. Dredging quantities for the years 2012-2015 were obtained from the SWG local area office. Dredging volumes per year vary significantly due to dredging needs, availability of funding, occasional needs for emergency dredging, and several other factors. Figure 2 is a comprehensive graph showing the cumulative dredging volume for the entire MSC. Based on the dredging history data gathered since 1957, the average yearly dredging rate for the entire MSC is 2,937,616 cubic yards per year (cy/year). The average dredging rate for the focus area of the study alone is approximately 558,380 cy/year.

MSC sediment data. Existing data were utilized to improve understanding of regional sediment transport in the area. Dredged material placement activities were gathered through discussions with SWG operations managers and engineers and by reviewing information from previous field surveys and investigations.

In 2013, SWG obtained sediment data for the entrance channel and study focus area of the MSC. Entrance channel sediment data were measured between Stations $-9+000$ and $-20+000$. Sediment for the entrance channel was measured to be composed of $41.8 \%$ sand, $27.2 \%$ silt, and $31 \%$ clay. The median grain size, $\mathrm{D}_{50}$, for the entrance channel was measured to be 0.074 millimeters (mm). Sediment data for the focus area were measured between Stations 25+000 and 60+000. Sediment for this area was composed of $22.7 \%$ sand, $39.7 \%$ silt, and $38.1 \%$ clay. The $\mathrm{D}_{50}$ for the focus area was measured to be $0.040 \mathrm{~mm}$. 


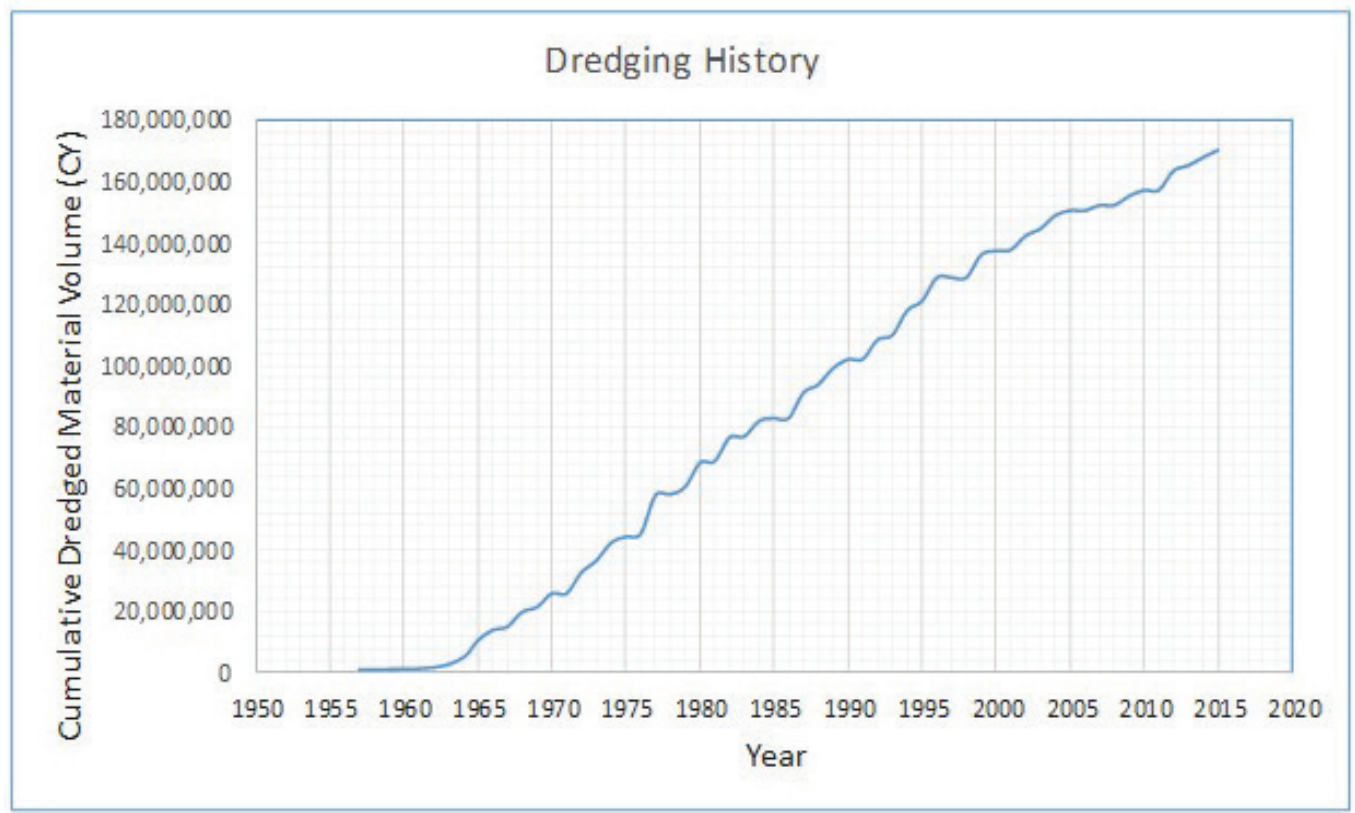

Figure 2. Cumulative dredging volumes for the MSC.

It should be noted that during this study very little data on the bay bottom were obtained other than sediment size data. In addition, it is recommended that further information pertaining to features of the bay in the study area, such as possible oyster reef locations and other environmental data, be gathered during future study efforts.

eHYDRO AND CHANNEL SHOALING ANALYSIS TOOL (CSAT): Survey data from 2002-2015 were gathered for use in updating the USACE Engineer Research and Development Center (ERDC) Coastal Modeling System (CMS) (Demirbilek and Rosati 2011) bathymetry for the study area and for the eHydro and Corps Shoaling Analysis Tool (CSAT) analysis (Dunkin and Mitchell 2015). Survey files were collected and processed for the entire MSC. Using the surveys, the eHydro Tool was run to produce a database for each survey. These were used as the inputs for the CSAT analysis. The databases were uploaded to the ERDC Enterprise server in Vicksburg, MS where the CSAT team was able to access and process them. The CSAT compared surveys between dredging periods to determine sedimentation within the ship channel as well as identify specific shoaling hot spots within the MSC. The CSAT produces a variety of outputs including a shoaling raster and the shoaling rates table. The CSAT results indicate an average shoaling rate of $4.66 \mathrm{ft} /$ year, and an average shoaling volume of 342,000 cy/year for channel Stations $0+000$ to $6+000$ of the focus area. It should be noted that these results are for $15 \%$ of the focus area. As such, these shoaling rates should be updated as additional surveys become available that cover the entire focus area. Table 2 contains the results that were determined by CSAT.

\begin{tabular}{|c|c|c|c|}
\hline Reach & $\begin{array}{l}\text { Average Shoaling } \\
\text { Rate (ft/yr) }\end{array}$ & $\begin{array}{l}\text { Average Volume } \\
\text { Rate (cy/yr) }\end{array}$ & $\begin{array}{l}\text { Area Coverage } \\
\text { Percent }\end{array}$ \\
\hline $\begin{array}{l}\text { MS_02_MPL_2 } \\
\text { (District Unique Identifier) }\end{array}$ & 4.66 & 342,000 & 15 \\
\hline
\end{tabular}


Figure 3 shows the shoaling raster that was produced from the CSAT outputs. Again, due to the limited survey data, only the green/yellow/red colored areas were analyzed by the tool. High shoaling rates are indicated in green, and low shoaling rates are indicated in red. The image shows higher levels of shoaling on the channel toes when first entering the bay. This raster, or a more complete raster if/as more surveys become available, will be added to ArcGIS Online and/or the SWG Enterprise databases. The data can then be used individually to determine shoaling rates in the area and any need for future analysis.

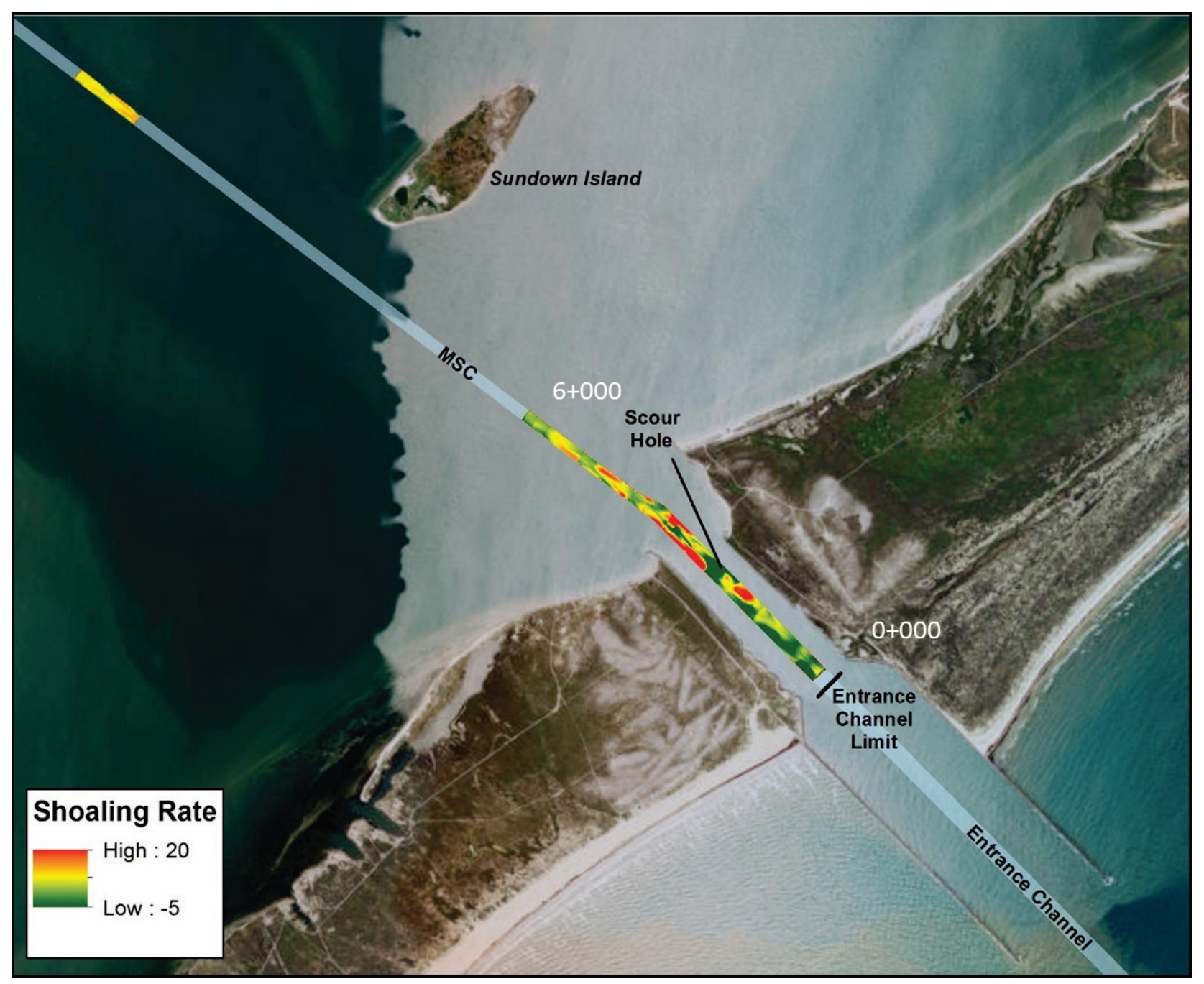

Figure 3. Shoaling raster produced from the Channel Shoaling Analysis Tool (CSAT) outputs.

NUMERICAL MODELING: The ERDC CMS was selected to quantify and simulate physical processes affecting the shoaling rates in the study area. The CMS uses an integrated numerical modeling system to model waves, currents, sediment transport, and morphology change at coastal inlets and entrances (Demirbilek and Rosati 2011). CMS modeling was used to evaluate the effectiveness of four identified alternatives in reducing shoaling in the MSC. The CMS model domain used for this study covers a $7 \times 7$ kilometer $(\mathrm{km})(4.3 \times 4.3$ mile) area of the Matagorda Region (Figure 4). The bathymetry was updated to current conditions for this modeling effort by using the survey data taken since the last update in 2012. 


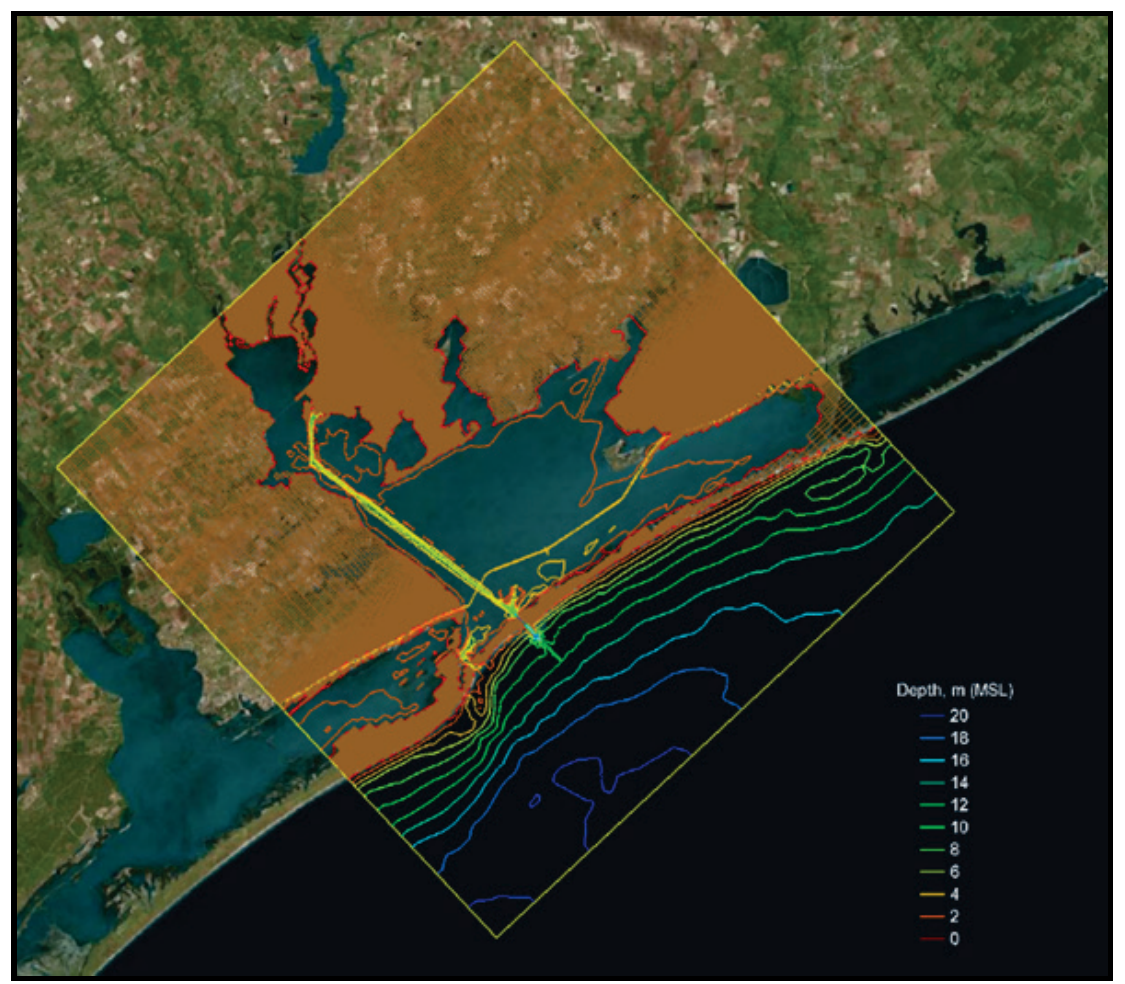

Figure 4. CMS domain for Lower Matagorda Ship Channel, Texas.

The CMS grid extends from the shallow north regions of the upper Matagorda Bay to the southern areas, reaching to the 20 meter $(\mathrm{m})(65 \mathrm{ft}$.) depth contour. The CMS model was calibrated with water level, current, and wave data collected around Matagorda Bay for the 59-day period of 1 January through 28 February 2014, using the same method applied and documented in two previous modeling studies (Rosati et al. 2011, Lambert et al. 2013).

Sediment in Matagorda Bay is mixed with increased percentages of sand near the Bay entrance and inlets along the coast. Increased silt and clay are found in other areas of the Bay. Five areas for sediment shoaling calculations were established (Figure 5) based on simulation results from CSAT as well as proximity to the PAs. The simulations verified that several sources were contributing to shoaling in the MSC. Modeling results indicated that the unconfined PAs produced a large amount of shoaling in the study area.

SEDIMENT BUDGET ANALYSIS: The Sediment Budget Analysis System (SBAS) (Rosati and Kraus 2003, Dopsovic et al. 2002 [rev. 2003]) was applied to compile historical sediment erosion and shoaling information in Matagorda Bay and gain greater knowledge of the relationship between sediment sources and sinks within the project area (Figure 6). There was no bulking factor applied to relate the shoreline-eroded material to the volume deposited in the channel. The difference due to consolidation could be significant, but no applicable information was available, so bulking was not considered a factor. The first part of this task consisted of reviewing previous work and summarizing coastal processes and operations for Matagorda Bay (Lambert et al. 2013, Thomas and Dunkin 2012, Kraus et al. 2008). 


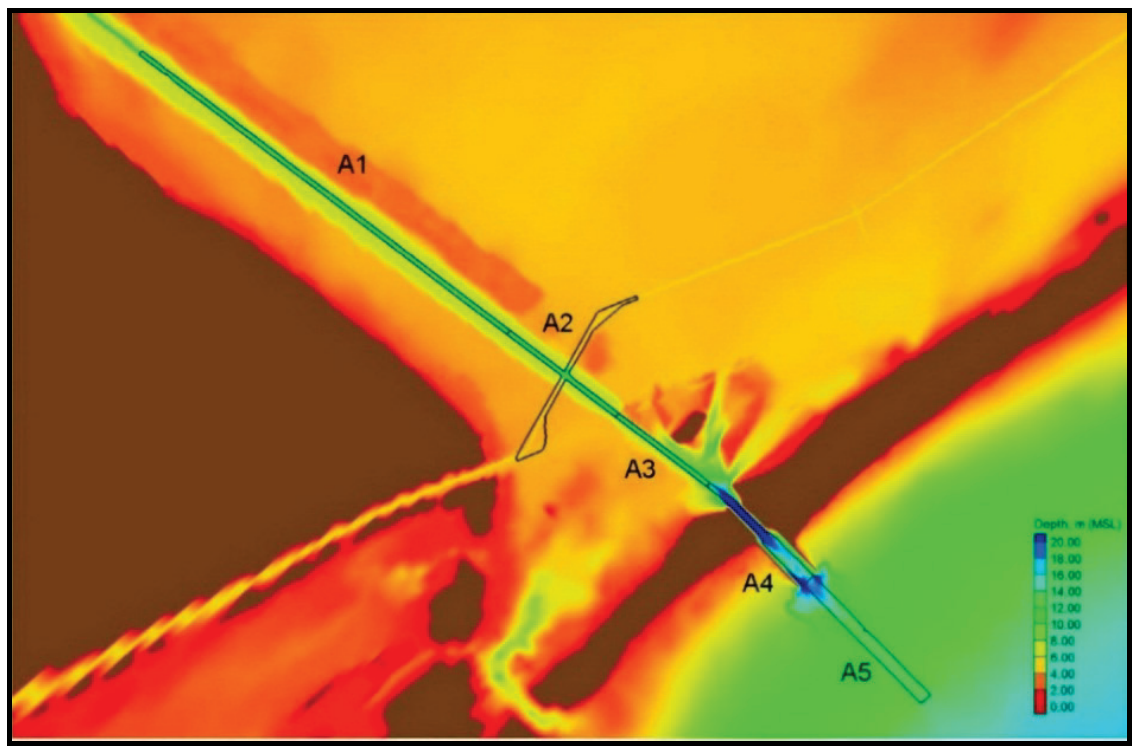

Figure 5. Sediment shoaling calculations areas A1 to A5.

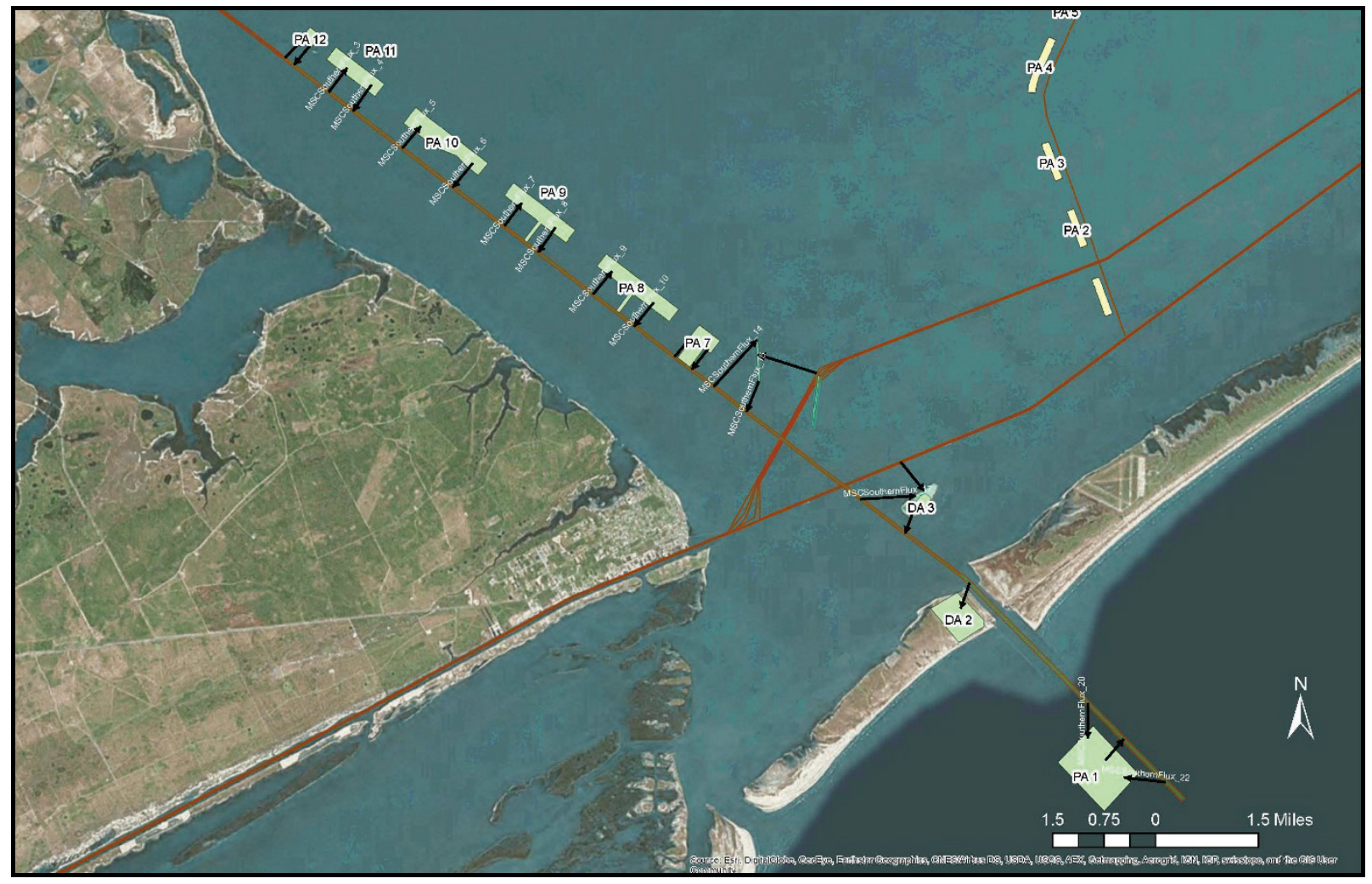

Figure 6. Sediment budget cells in the study focus area.

Several assumptions were made in creating this sediment budget:

- Sediment is moving from unconfined PAs into the MSC.

- Additional sediment is suspended in Matagorda Bay from a variety of sources, including rivers and other water bodies discharging into the Bay.

- Sediment is moving into and settling in the study focus area via the MSC. 
- Averages of dredging data over the last 25 years were used, assuming they best reflected current conditions.

- Thirty\% uncertainty was used in the budget, which is generally considered an acceptable standard amount for this type of analysis.

The following general conclusions are presented based on the sediment budget analysis of historical data:

- In the study focus area where shoaling issues are most prevalent, $40-45 \%$ of the shoaling material in the problem area was estimated to be caused by a combination of ebb/flood tides and material transported from unconfined PAs on the east side of the MSC.

- Approximately $20-25 \%$ of sediment shoaling in the study focus area is from suspended material settling throughout Matagorda Bay. Material from water bodies discharging into the bay is carried by currents, wave action, and other methods. Erosion of shorelines and recreational beaches around the bay and transport of material from the various PAs (along the MSC, the GIWW, and the channel to Palacios) all contribute to the suspended material in the bay.

- Within the entrance channel and inlet to the bay, the study showed an overall shoaling deficit, which created several large scour holes.

- Within the entrance channel and inlet to the bay, there are also isolated areas of heavy shoaling.

ANALYSIS OF ALTERNATIVES: The MSC Project Delivery Team members developed several potential alternatives to reduce shoaling in the MSC. Four of the alternatives were selected for further analysis and modeling. The primary metric for selecting one or more of these alternatives is quantifiable shoaling reduction. The alternative(s) must also be economically feasible and have the potential to be approved by resource agencies. Beneficial use is preferred if possible, but is not a necessity. The following alternatives were posed for consideration:

\section{Alternative 1: Move unconfined PAs 6 through 10 from the east side to the west side of the channel. A series of unconfined PAs are located on the east side of the MSC (Figure 1). Dredged material is placed in these PAs, and this same material is believed to settle back into the MSC. Modeling indicated a reduction in shoaling in the MSC if the unconfined PAs 6 through 10 were moved to the west of the channel centerline (Figure 7). Waves approaching the channel from the east side with wind driven currents cause slightly more westbound sediment transport than eastbound transport. The sediment tends to settle in the channel as the current slows down crossing the deep channel area. This measure is cost efficient, as the dredging cost would be approximately the same (Reference Table 3 in "Summary of Modeling Results and Alternative Selection" for a summary of shoaling quantities for the alternatives.)}

Additional considerations to include are the condition of the bay bottom on the west side of the MSC and whether any environmentally sensitive areas exist that would require avoidance or mitigation. National Environmental Protection Act (NEPA) coordination, and coordination with other appropriate entities, would need to occur before this alternative could be implemented. 


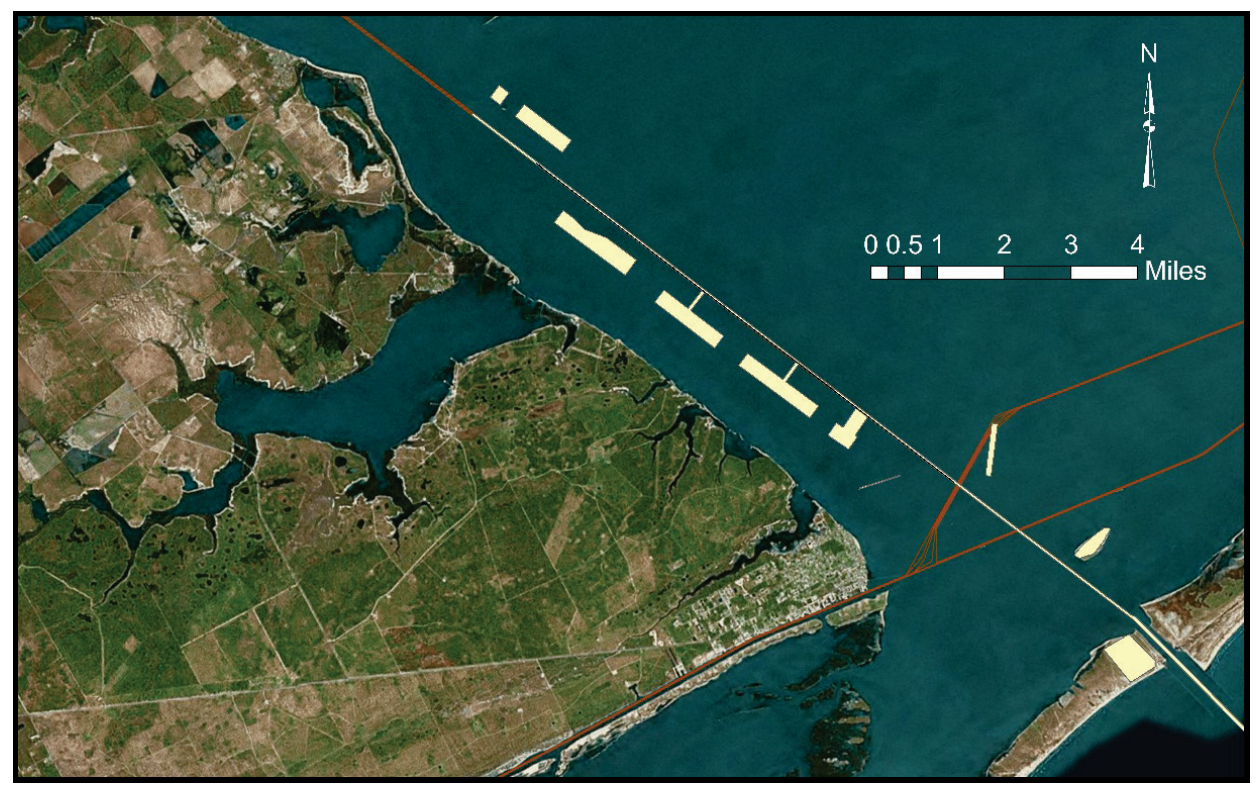

Figure 7. Alternative 1 concept, PAs 6 through 10 relocated to west side of MSC.

CMS modeling predicted that ebb tides could cause some material from the PAs on the west side to migrate into the MSC. Also, it is known that major pipeline corridors pass through this area. The exact locations are unknown and coordination with the pipeline owners would need to occur. The pipelines should not require any relocation or modification, but it should be verified that the change in location of these PAs would not cause any issues.

Alternative 2: Semi-confine PAs 6 through 10. This alternative would semi-confine the open PAs 6 through 10 on the east side of the MSC (Figure 8) to reduce the rate of shoaling. Currently all PAs in the area are unconfined. The confinement would delay the flow of dredged sediments from the PAs back into the MSC. This would create less shoaling in the MSC and less frequent dredging requirements. Confinement could possibly lead to emergent or expanding PAs, which could have environmental impacts. NEPA coordination, and coordination with other appropriate entities, may need to occur to address any environmental issues before this alternative could be implemented.

\section{Alternative 3: Place dredged material on Sundown Island instead of unconfined} PAs. Sundown Island (Figure 9) was created in 1962 using MSC dredged material. This is the Audubon Texas Society's largest bird sanctuary on the Texas coast (Atkins 2014). After the GIWW alignment was shifted north in 2007 to make use of naturally deep water, USACE dredged material effectively stopped being placed on Sundown Island. Although Sundown Island currently is one of the largest and most diverse rookeries on the Texas coast, it erodes due to tides, wave action, and wakes from passing ship traffic. Additionally, erosion protection measures implemented in the past have begun to fail and are no longer functioning as intended. Erosive forces have led to the reduction in size of the Island from 81 acres in 2001 to its current size of 65 acres. The maximum measured acreage for Sundown Island on record is 81 acres in 2001 (Atkins 2014). 


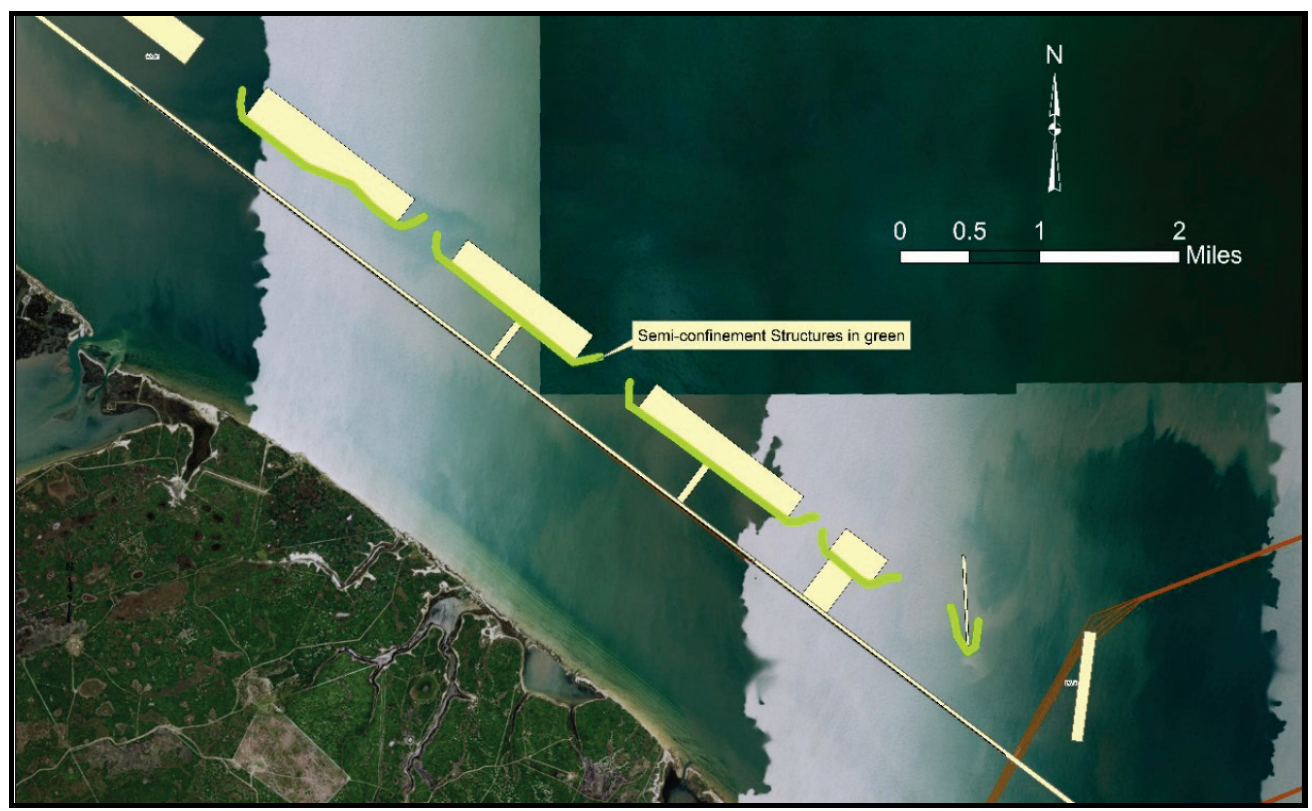

Figure 8. Alternative 2 concept, semi-confined PAs 6 through 10 on east side of MSC.

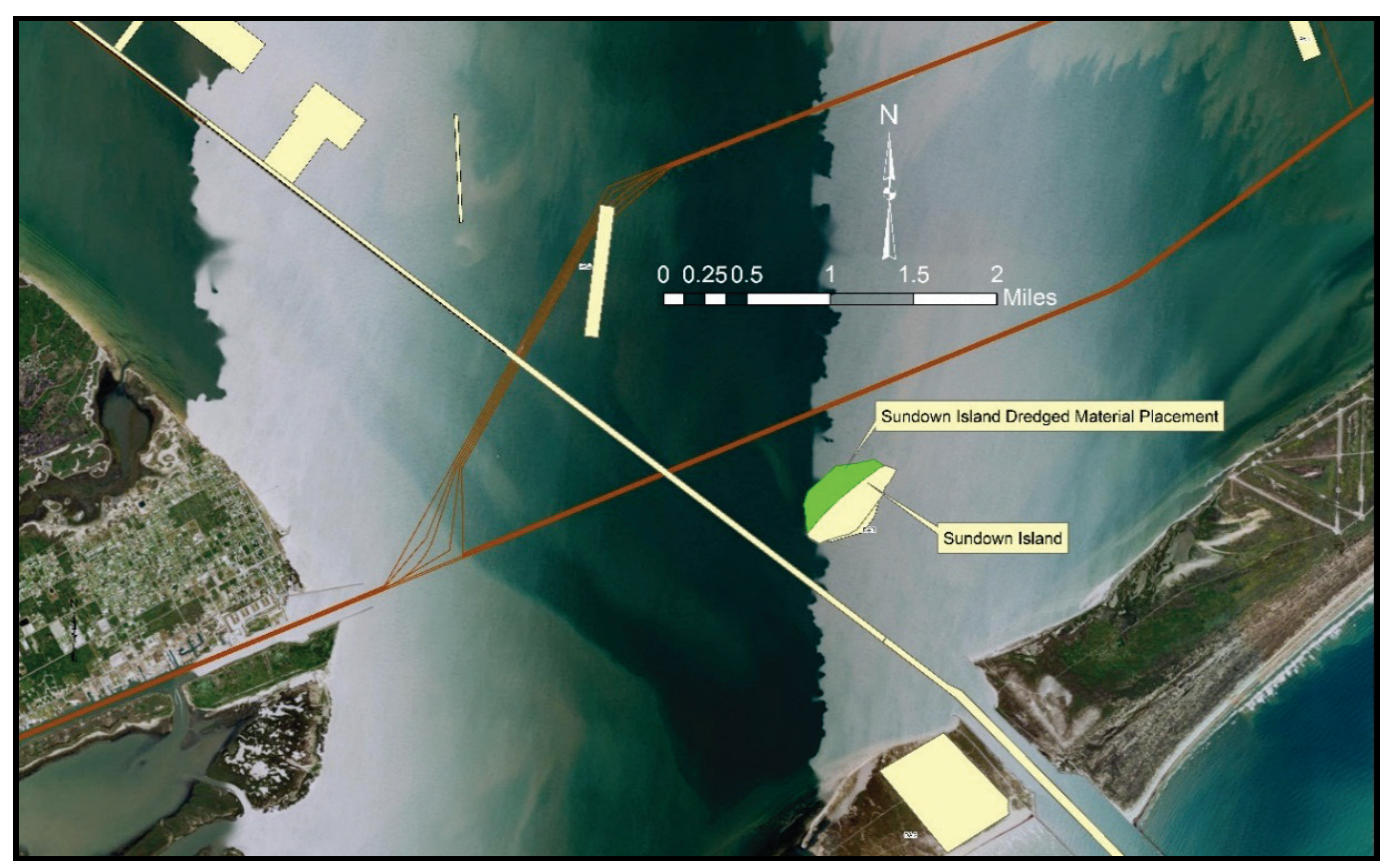

Figure 9. Alternative 3 concept, Sundown Island expansion.

Sundown Island is located just inside the MSC inlet (Figure 8). CMS modeling showed currents and tidal velocities are lowest on the northern side of the Island. Audubon Texas has expressed wishes to expand the Island to 100 acres (Atkins 2014). It is estimated in the Atkins (2014) report that approximately 450,000 cy of material would be required to establish a 100 acre Island. Additional renourishments of varying quantity and frequency, depending on the design selected, would be needed. The Atkins (2014) report preliminarily investigates several possible erosion control measures to help protect the island from erosive forces. 
It is not recommended to place material along the south side of the Island without erosion control structures. More detailed study and environmental coordination regarding sea grass known to exist around the Island would be needed before implementing this alternative. This alternative would require more study and identification of funding sources for maintenance, renourishment, possible erosion control structures, and environmental impacts. An advantage of this alternative is that dredged material would be beneficially used.

Alternative 4: Move material in PAs 6 through 10 to beach or other location(s). This alternative removes all material from unconfined PAs 6 through 10 (Figure 10). Alternative 4 assumes another justifiable location could be found to place the dredged material. Options considered for placement of this material include beach nourishment along Matagorda Bay beaches and possible placement into upland sites. Cost is likely a primary issue that could exclude this alternative due to long pumping distances or other increased costs. This alternative would need more detailed study, and additional coordination with entities such as NEPA and Audubon Texas. A separate entity (or entities) would likely be needed to cover any increased costs.

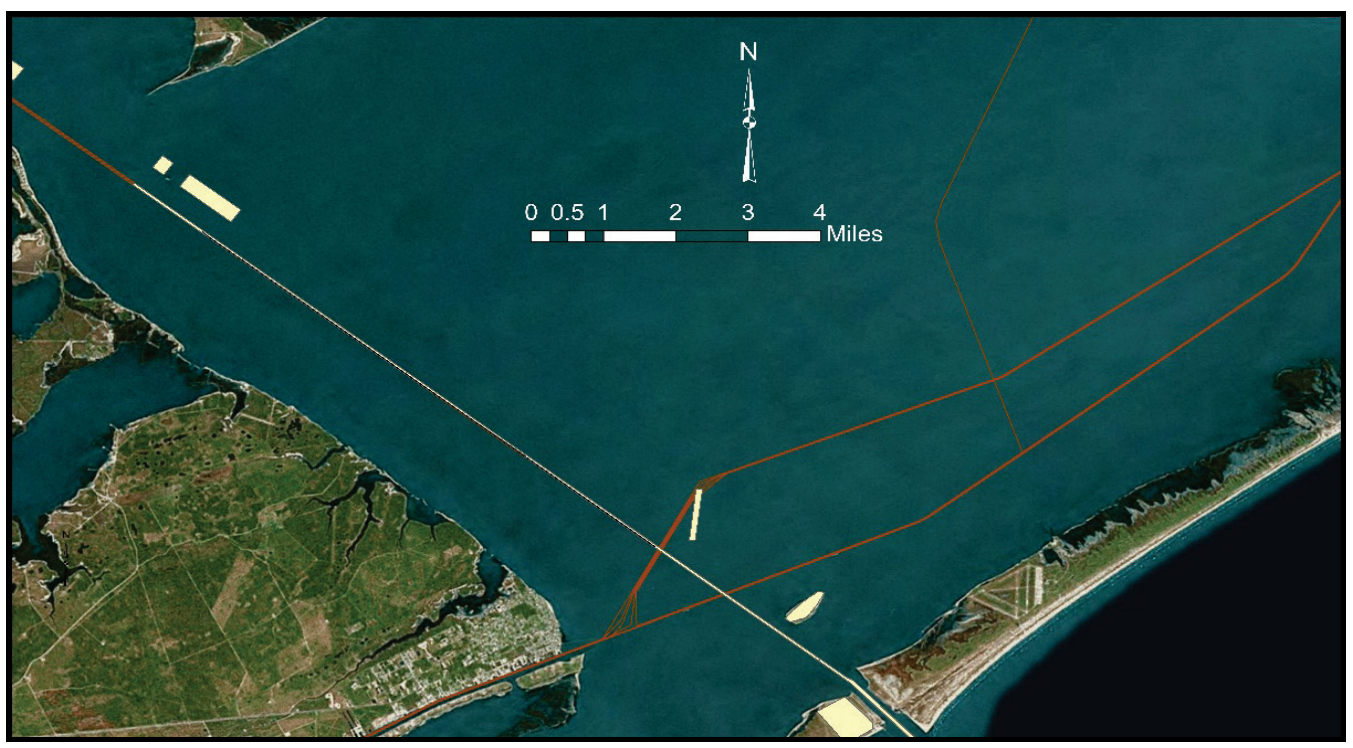

Figure 10. Alternative 4 concept, remove material from PAs 6 through 10 and place elsewhere.

SUMMARY OF MODELING RESULTS AND ALTERNATIVE SELECTION: Table 3 shows the calculated shoaling rates for the existing conditions and for the four alternatives analyzed. Area A4 is in an erosive state for all alternatives; therefore, it is not included in this summary table.

CONCLUSIONS: Based on the analysis performed and modeling results, it is recommended that Alternatives 2 and 3 be pursued and studied further for reducing shoaling in the MSC study area. Alternative 2, semi-confining PAs 6 through 10, would reduce the shoaling in the MSC by 26,120 cy. Alternative 3, placing material on Sundown Island, would reduce the shoaling in the MSC by $34,820 \mathrm{cy}$. Together, it is predicted these two alternatives could reduce shoaling up to $60,940 \mathrm{cy}$. This is an approximate reduction of $19.8 \%$ in shoaling in the study focus area. If a combination of Alternatives 2 and 3 is used, these numbers may vary. Additional features such as hardened erosional control structures on Sundown Island could further reduce shoaling in the MSC. 
ERDC/TN RSM-17-1

June 2017

Table 3. Calculated channel shoaling volume (cy), (September 2013 - February 2014).

\begin{tabular}{||l|c||c||c||c|c||}
\hline Area & A1 & A2 & A3 & A5 & \multicolumn{1}{|c||}{ Total } \\
\hline Alternative 0 (existing conditions) & 55,570 & 195,240 & 28,380 & 29,070 & 308,260 \\
\hline Alternative 1 (Move PAs 6-10 West of MSC) & 44,660 & 194,980 & 28,880 & 29,080 & 297,600 \\
\hline Alternative 2 (Semi-Confine PAs 6-10) & 54,110 & 183,070 & 24,350 & 20,610 & 282,140 \\
\hline $\begin{array}{l}\text { Alternative 3 (Place dredged material on } \\
\text { Sundown Island in lieu of unconfined PAs) }\end{array}$ & 54,480 & 180,210 & 17,990 & 20,760 & 273,440 \\
\hline $\begin{array}{l}\text { Alternative 4 (Move Material in PAs 6-10 to } \\
\text { beach or other location away from MSC) }\end{array}$ & 58,740 & 189,470 & 22,360 & 20,540 & 291,110 \\
\hline
\end{tabular}

This RSM-TN is intended to improve RSM communication both within SWG and between SWG and its partnering organizations.

ADDITIONAL INFORMATION: This Regional Sediment Management Technical Note (RSMTN) was prepared as part of the USACE Regional Sediment Management (RSM) Program by Eric Wood, Tricia Campbell, Matt Duke, and Leslie Olson of the U.S. Army Engineer District, Galveston (SWG); and Lauren Dunkin and Lihwa Lin of the USACE Engineer Research and Development Center (ERDC), Coastal and Hydraulics Laboratory (CHL). Additional information regarding the RSM Program can be found at the RSM website http://rsm.usace.army.mil, or by contacting the USACE RSM Program Manager, Linda Lillycrop at Linda.S.Lillycrop@usace.army.mil. Information pertaining to this RSM-TN may be obtained from the Galveston District Point of Contact, Paul Hamilton at Paul.B.Hamilton@usace.army.mil.

This ERDC/TN RSM-17-1 should be cited as:

Wood, E., T. Campbell, M. Duke, L. Olson, L. Dunkin, and L. Lin. 2017. Identification of alternatives to reduce shoaling in the Lower Matagorda Ship Channel. ERDC/TN RSM-17-1. Vicksburg, MS: U.S. Army Engineer Research and Development Center. http://dx.doi.org/10.21079/11681/22408

\section{REFERENCES}

Atkins. 2014. Sundown Island shoreline protection and restoration project: Conceptual design alternative analysis. Houston, TX: Prepared for Audubon Texas, San Antonio, TX.

Demirbilek, Z. and J. Rosati. 2011. Verification and validation of the Coastal Modeling System; Report 1: Summary report. ERDC/CHL-TR-11-10. Vicksburg, MS: U.S. Army Engineer Research and Development Center.

Dopsovic, R., L. Hardegree, and J. D. Rosati. 2002 (rev. 2003). Sediment budget analysis system-A: SBAS-A for Arcview@ application. ERDC/CHL CHETN-XIV-7. Vicksburg, MS: U.S. Army Research and Development Center.

Dunkin, L. M. and K. N. Mitchell. 2015. Quantitative approach to navigation channel asset management. In Proceedings, Western Dredging Association and Texas A\&M University Center for Dredging Studies' "Dredging Summit and Expo 2015." 22-25 June, Houston, TX.

Kraus, N., L. Lin, E. Smith, D. Heilman, and R. Thomas. 2008. Long-term structural solution for the mouth of Colorado River navigation channel, Texas. ERDC/CHL TR-08-4. Vicksburg, MS: U.S. Army Engineer Research and Development Center. 
Lambert S., S. Willey, T. Campbell, R. Thomas, H. Li, L. Lin, and T. Welp. 2013. Regional sediment management studies of Matagorda Ship Channel and Matagorda Bay System, Texas. ERDC/CHL TR-13-10. Vicksburg, MS: U.S. Army Engineer Research and Development Center.

Lillycrop, L. S., J. McCormick, L. Parsons, and M. Chasten. 2011. Adaptive management through regional sediment management. In Proceedings, Western Dredging Association (WEDA XXXI) Technical Conference and Texas A\&M University (TAMU 42) Dredging Seminar. 5-8 June, Nashville, TN.

Rosati, J. and N. Kraus. 2001 (rev. 2003). Sediment Budget Analysis System (SBAS): Upgrade for regional applications. ERDC/CHL CHETN-XIV-3. Vicksburg, MS: U.S. Army Engineer Research and Development Center. http://chl.erdc.usace.army.mil/library/publications/chetn/pdf/chetn-xiv-3.pdf

Rosati, J., A. E. Frey, M. E. Brown, and L. Lin. 2011. Analysis of dredged material placement alternatives for bottleneck removal, Matagorda Ship Channel, Texas. ERDC/CHL TR-11-2. Vicksburg, MS: U.S. Army Engineer Research and Development Center.

Thomas, R. and L. Dunkin. 2012. Erosion control and environment restoration plan development, Matagorda County, Texas; Phase 1: Preliminary investigation. ERDC/CHL TR-12-11. Vicksburg, MS: U.S. Army Engineer Research and Development Center.

United Research Services (URS). 2007 (rev. 2014). Engineering appendix: Matagorda Ship Channel improvement project. Prepared for Calhoun Port Authority. Houston, TX: URS Corporation.

U.S. Army Corps of Engineers (USACE). 2002. Erosion, transport, and deposition of cohesive sediments. In Coastal Engineering Manual, Part III: Coastal Sediment Processes. EM-1110-2-1100. Washington, D.C.: U.S. Army Corps of Engineers.

U.S. Army Corps of Engineers (USACE). 2009. Final environmental impact statement for Calhoun Port Authority: Proposed Matagorda ship channel improvement project; Calhoun and Matagorda counties, Texas. Volume IV, Appendices L-N. Galveston, TX: U.S. Army Corps of Engineers, Galveston District.

NOTE: The contents of this technical note are not to be used for advertising, publication, or promotional purposes. Citation of trade names does not constitute an official endorsement or approval of the use of such products. 